\title{
MASARYKOVA STÁTNÍ ŠKOLA ZDRAVOTNÍ A SOCIÁLNÍ PÉČE V MEZIVÁLEČNÉM OBDOBí
}

\author{
RŮŽENA ZAORALOVÁ - ROMAN ZAORAL
}

\author{
MASARYK STATE SCHOOL FOR NURSES IN PUBLIC HEALTH AND SOCIAL CARE \\ IN THE INTERWAR PERIOD
}

This study focuses on the first three years (1936-1938) in the history of Masaryk State School in Prague, which introduced a new integrated approach to the duties and competences of nurses and social workers in interwar Czechoslovakia. This unique institution was supported by the Rockefeller Foundation. Surprisingly, although education of knowledgeable nurses in public health and social work is a highly relevant subject, especially in connection with a growing role of home care, this school had as yet received little attention. The study is based on an analysis of Czechoslovak and US (Rockefeller Foundation) archival sources of institutional, legislative, and personal nature (correspondence and diaries). The authors take into account 1920s and 1930s discussions on the notion of a combined nurse and social worker; highlight problems which attended the establishment of Masaryk State School, and show how its profile and curriculum differed from other nursing schools in interwar Czechoslovakia.

Keywords: Masaryk State School - education in nursing and social work - health policy - teaching focus - interwar Czechoslovakia (1918-1938)

DOI: $10.14712 / 23365730.2018 .31$

Masarykova státní škola zdravotní a sociální péče (MSŠZSP) představovala v meziválečném Československu nový typ ošetřovatelských škol, o jehož celosvětové rozšíření po první světové válce intenzivně usilovali pracovníci Rockefellerovy nadace (Rockefeller Foundation, RF). Koncept školy vycházel z teorie o racionalizované medicíně a humánní ekonomii, které prosazoval belgický sociální lékař René Sand (1877-1953). Její oporou byla starší anglická teze o ,začarovaném kruhu bídy a nemoci“: lidé jsou nemocní, protože jsou chudí, a chudí jsou proto, že jsou nemocní. Tento začarovaný kruh měl být podle Sanda rozetnut racionalizačními opatřeními v péči o zdraví. ${ }^{1}$ Finanční prostředky na tato opatření měly pocházet převážně od podnikatelů. Nejvýraznějším př́ikladem byl bezpochyby americký petrolejářský magnát a filantrop John D. Rockefeller (1839-1937), jehož nadace, založená v roce 1913 s nesmírně ambiciózní vizí zajistit blahobyt lidstva na celém světě, v roce 1916 finančně podpořila vznik School of Hygiene and Public Health jako součásti Univerzity Johnse Hopkinse v Baltimoru. Šlo o první instituci svého druhu na

1 Kerstin Eilers, René Sand (1877-1953) and His Contribution to International Social Work, IASSW-President 1946-1953, Social Work and Society 5/1, 2007, nestr. Dostupné z: <http://www.socwork.net/sws/article /view/124/540> (6. 2. 2017). 
světě. Druhou školou založenou Rockefellerovou nadací v USA se stala Harvard School of Public Health v Bostonu. Škola vznikla již v roce 1913, k Harvardově univerzitě však byla přičleněna teprve $\mathrm{v}$ roce 1922.

Významnou platformu k prosazení Sandova pojetí představovala první světová konference o sociální práci, která se uskutečnila v Paříži v roce 1928 a kterou řídila Alice Masaryková (1879-1966), první předsedkyně Československého červeného kř̌iže, spolu s René Sandem, který tehdy zastával pozici generálního tajemníka Ligy Červených křížůu. Konference podnítila mezinárodní diskusi o novém typu sociálně zdravotní sestry a stala se zároveň impulsem $\mathrm{k}$ budování mezinárodní sítě škol zaměřených na výchovu těchto pracovnic. Důraz byl prítom kladen na mezinárodní vztahy, nebot' sociální péče se podle přesvědčení Alice Salomonové (1872-1948), přední německé průkopnice na tomto poli, nemůže ze své podstaty uzavírat do hranic jednotlivých států. ${ }^{2}$

$\mathrm{V}$ rámci racionalizačního hnutí bylo zapotřebí, aby nemocnice $\mathrm{v}$ sobě soustředily jak všechny formy léčebné a preventivní péče, tak i praktické sociálně-lékařské činnosti. Soustředění všech sociálně-zdravotních aktivit do jednoho místa mělo zaručovat hospodárnost a nižší finanční náročnost. Vzhledem k stálému nedostatku financí ve státní správě byla racionalizace zdravotnictví nezbytnou podmínkou jeho rozvoje. Cílem měla být integrace zdravotní a sociální péče v rámci holistického pojetí člověka a snaha poskytnout nemocnému odbornou péči i po odchodu z nemocnice. Vycházelo se z představy, že tohoto cíle mohou dosáhnout jen státní nemocnice; ostatně i proto se RF primárně orientovala na spolupráci se státem. Vzorovými nemocnicemi se měly stát zejména ty státní, které Československá republika převzala podle recipovaných mad’arských zákonů (Bratislava, Košice, Žilina, Chust), a také podle zákona č. 242/1920 Sb. postátněné nemocnice (Královské Vinohrady, Ostrava, Lučenec a Mukačevo). ${ }^{3}$ Vedoucí pozici mezi nimi zaujímala nemocnice na Královských Vinohradech, při níž vznikla v roce 1936 škola vzdělávající sociálně-zdravotní typ sestry. Díky iniciativě lékaře Bohuslava Alberta se model moderního nemocničního zařízení podařilo prosadit rovněž v soukromé nemocnici Tomáše Bati ve Zlíně. ${ }^{4}$ Provoz většiny zdravotnických zařízení v ČSR si naopak vystačil s tradičním konceptem nemocniční sestry.

Po dlouhých diskusích mezi státem, reprezentovaným ministerstvy zdravotnictví, sociální péče a školství, a RF, která nový typ sociálně zdravotní sestry prosazovala a finančně podporovala, převládlo také v odborných kruzích v Československu přesvědčení, že stávající školní instituce v Praze (Státní ošetřovatelská škola a Vyšší škola sociální péče) neposkytují dostatečnou průpravu pro moderní sociálně-zdravotní práci a že je proto třeba zř́́dit školu nového typu, která by připravila absolventy s celostním př́stupem k člověku. Toto pojetí vyžadovalo širší znalosti ze sociálních, zdravotních, právních i pedagogických disciplín. $^{5}$

2 Alice SAlomon, Die Bedeutung internationaler Kongresse für die soziale Arbeit, Deutsche Zeitschrift für Wohlfahrtspflege 10, 1927, s. 495-496.

3 Zákon č. 242/1920 Sb. o prozatimni úpravě právních pomérů ústavů léčebných a humanitních v republice Československé, $\$ 4$.

4 Hana MÁšová, Účelnost pro vyšši humanitu - lékař a organizátor Bohuslav Albert, Dějiny věd a techniky (dále DVT) $31 / 1,1998$, s. 1-11.

5 Československá vlastivěda, 2, Člověk, Praha 1933, s. 534-535; srov. též Monika VamBerová, Prof. MUDr. Theodor Gruschka (1888-1967). Osud mezi Prahou a Jeruzalémem, diplomová práce, Fakulta sociálních věd UK, Praha 2001, s. 78. 
Výchova sociálně-zdravotní sestry byla ve třicátých letech 20. století v odborných ošetřovatelských kruzích považována za správnou cestu pro směřování oboru. Vycházelo se z představy o blahobytné společnosti (welfare society), v níž smyslem není jen léčit, ale zejména nemocem předcházet, a to s ohledem na zájmy nemocného a jeho rodiny a tím i celé společnosti. Místo do té doby výhradně praktikované léčby nemoci mělo primárně jít o péči o zdraví. Sociálně-zdravotní sestrou se rozuměla ošetřovatelka, která ovládá zdravotní péči léčebnou a preventivní, sociální hygienu, propagaci zdravotních zásad a ošetřovatelskou službu v domácím prostředí pacienta. ${ }^{6}$ Takový typ ošetřovatelek v Československu neexistoval, protože první ošetřovatelské školy se zaměřovaly výhradně na výchovu pracovnic pro nemocniční službu.

V roce 1925 působily na kontinentu již čtyři školy financované Rockefellerovou nadací; nejvýznamnější z nich byla v Lyonu a další pak v Krakově, Bělehradě a Záhřebu. Specifikem těchto škol bylo, že se v nich vzdělávaly budoucí sestry jak pro nemocniční péči, tak pro práci ve veřejném zdravotnictví a že byly přímo spojeny nejen s nemocnicí, ale také s univerzitou. ${ }^{7}$ Dlouhodobým strategickým cílem RF bylo vybudovat co možná nejhustší sít' moderních ošetřrovatelských škol ve světě a postupně omezovat počty zahraničních stipendistek na angloamerických školách. ${ }^{8}$

Záměr RF zřídit takovou školu i v Československu se poprvé objevil v situační zprávě o stavu ošetřovatelského školství v Československu z roku 1922, jejíž autorkou byla Frances Elisabeth Crowellová, zástupkyně Mezinárodní zdravotní divize RF pro Evropu. ${ }^{9}$ Uskutečnění tohoto plánu ovšem naráželo na řadu problémů. Na rozdíl od praxe ve Spojených státech školu nebylo možné zřídit bez schválení státních orgánů; a k tomu chyběla jak př́islušná legislativa, tak vůle kompetentních orgánů. Nerozhodnost a často i neochota československých úřadů učinit relevantní rozhodnutí vedly později Crowellovou ke konstatování, že sousední země střední a jihovýchodní Evropy (Polsko, Mad’arsko, Jugoslávie), které měly horší výchozí pozici, udělaly během dvacátých let ve veřejném zdravotnictví a ošetrrovatelském školství větší pokrok než Československo. ${ }^{10}$

Crowellová vedla na toto téma řadu neúspěšných jednání také se Sylvou Macharovou, absolventkou vídeňské ošetřrovatelské školy Rudolfinerhaus, která v letech 1923-1931 zastávala post ředitelky pražské ošetřovatelské školy. Macharová nechtěla udělit souhlas k přidělení pozemku na stavbu nové školy a odmítala rovněž myšlenku včlenit ji do struktury Státního zdravotního ústavu (SZÚ) a využít klinických možností nedaleké Vinohradské nemocnice s odůvodněním, že by prý bylo obtížné pracovat s řádovými sestrami, jejichž

6 Výčet speciálních požadavků pro sociálně zdravotní službu sester podává Arnoštka RiPKovÁ, Poslání ošetřovatelky pri vztahu nemocnic $k$ okoli (Zpráva pro mezinárodní sjezd nemocnic v Řimě 1935), Československá nemocnice (dále ČN) 5, 1935, s. 159-163.

7 The Rockefeller Foundation Annual Report 1925, New York 1925, s. 422. Dostupné z: <https://www .rockefellerfoundation.org/app/uploads/Annual-Report-1925.pdf> (6. 2. 2017).

8 DME Nursing Programme (Revised January 1928), in: 100 Years: The Rockefeller Foundation [online], (C) The Rockefeller Archive Center. Dostupné z: <http://rockefeller100.org/files/original/d2366beaed952cf d53ed18f6fb2dfd90.pdf> (6. 2. 2017).

9 Americká ošetřovatelka o našich poměrech, Zprávy Československého červeného křiže (dále Zprávy ČSČK) 3, 1923, s. 14-16.

10 Elizabeth Vickers, Frances Elisabeth Crowell and the Politics of Nursing in Czechoslovakia after the First World War, Nursing History Review 7, 1999, s. 67-96, zde s. 88. 
mentalita je odlišná od mentality laických sester. Ideálem sestry bylo podle Macharové fungovat jako asistentka lékaře. ${ }^{11}$

Spor se vedl o včlenění veřejné zdravotní péče do ošetřovatelského programu. Odpor vůči nové škole, jež měla propojovat sociální a ošetřovatelskou péči, totiž vzbuzovaly obavy sociálních pracovnic, že by musely soutěžit na trhu práce s ošetřovatelkami školenými v komunitní péči a že by stát mohl Vyšší školu sociální péče zrušit, $\mathrm{k}$ čemuž také nakonec došlo. Absolventky této školy intervenovaly v roce 1927 u různých úradů, aby místa pro sociální práci byla obsazována pouze kvalifikovanými sociálními pracovníky. V reakci na to svolalo vedení pražské ošetřovatelské školy 1. června 1927 poradu o reorganizaci Státní ošetřovatelské školy a Vyšší školy sociální péče. ${ }^{12}$ Rezoluce žádala obě kompetentní ministerstva (zdravotnictví a sociální péče), aby se pokračovalo v jednání o tom, do jaké míry by bylo přičlenění obou škol pod stejné rízení možné. Vycházelo se z představy, že sociálně-zdravotní sestra by měla být vzdělávána na jedné škole, kterou by řídilo jedno ministerstvo. Jednání však nebyla př́iliš efektivní, nebot' v listopadu 1929 ministerstvo zdravotnictví odmítlo projednávat návrh týkající se profilu a uplatnění absolventek obou škol v praxi s odůvodněním, že je stálý nedostatek kvalifikovaných sil, takže je účelné, aby se v sociálně zdravotní službě uplatňovaly absolventky obou škol. ${ }^{13}$

Od počátku se počítalo s tím, že nová škola bude spojena s Vinohradskou nemocnicí a se SZÚ. Plánem na jeho zř́zení se zabýval již ministr zdravotnictví Vavro Šrobár (14. listopadu 1918 - 15. zárí 1920). Za jeho působení byl sjednán dar RF na vybudování ústavu. Smlouvu mezi ministerstvem zdravotnictví a RF z 25. srpna 1921, která obsahovala závazek nadace přispět na výstavbu ústavu částkou 26984600 Kč za podmínky, že ministerstvo zajistí k témuž účelu nejméně 23471700 Kč a že vybudování této instituce nebude trvat déle než šest let, podepsal tehdejší ministr Ladislav Procházka (15. září 1920 - 26. záŕí 1921) ${ }^{14}$ Pro ústav byl vybrán pozemek v bezprostředním sousedství Vinohradské nemocnice, plány navrhl architekt Rudolf Kvěch. Vznik a koncepce SZÚ nebyly dílem jedné osobnosti nebo jedné skupiny odborníků, ale výsledkem široké domácí diskuse, mezinárodních kontaktů, vývoje veřejného zdravotnictví v zahraničí a specifických podmínek v poválečném Československu. Ústav byl slavnostně otevřen 5. listopadu 1925.

Nedostatek pracovníků i financí a odpor univerzitních institucí, jejichž zástupci považovali nově založený ústav, první svého druhu ve střední Evropě, za nevítanou konkurenci, však znemožňovaly rozvinout vědecký program v plném původně zamýšleném rozsahu. Teprve ve třicátých letech se podařilo vybudovat pevnou organizační strukturu ústavu

11 Tamtéž, s. 85, s odkazy na deník Frances Crowellové, uložený v Rockefeller Archive Center v New Yorku; srov. též Elizabeth Vickers, Frances Elisabeth Crowell. An Evaluation of a European Nursing Experience, diplomová práce, The University of West Florida, Pensacola 1996, s. 76. Dostupné z: <http://etd.fcla.edu/WF /WFE0000064/Vickers Elizabeth Dwyer 199612 MA.pdf $>$ (6. 2. 2017).

12 Archiv hlavního města Prahy (dále AHMP), fond Masarykova státní škola zdravotní a sociální péče, podací protokol české ošetřovatelské školy, záznam č. 104, 1. 6. 1927. Do tohoto nezpracovaného fondu je uvedený protokol zařazen chybně, nebot' pochází od jiného původce. Zájem o vzdělání v oblasti sociální péče projevovaly i samy žákyně pražské ošetřovatelské školy. Srov. AHMP, fond Česká státní škola ošetřovatelská, Praha 2, Nové Město, Ječná 4, k. 1, dopis studentek ošetřovatelské školy z 2. 2. 1929.

13 AHMP, f. Masarykova státní škola zdravotní a sociální péče, podací protokol české ošetřovatelské školy, záznam č. 207, 19. 11. 1929; srov. též Růžena ZAORALOvÁ, Ošetrovatelské školství mezi tradici a modernitou: snahy o prosazeni anglosaského modelu v meziválečném Československu, DVT 49/2, 2016, s. 87-107, zde s. $105-106$.

14 Jaroslav Kříž - Renata Beranová, Historie Státního zdravotního ústavu v Praze, Praha 2005, s. 9. 
s následující náplní: výroba sér a očkovacích látek, biologická kontrola léčiv, bakteriologická a sérologická diagnostika, sociální hygiena, zdravotní výchova a propagace, zkoumání potravin a léčiv a chov pokusných zviřat. Součástí ústavu měla původně být také škola pro sestry sociálně-zdravotní péče, prosazovaná Bohumilem Vackem, ředitelem SZÚ (19281937). ${ }^{15}$ Pro odpor učitelů lékařských fakult v Praze a Brně však škola nakonec $\mathrm{k}$ SZÚ připojena nebyla. Jeden z odpůrců, Josef Roček, profesor hygieny na brněnské univerzitě, odůvodňoval zamítavé stanovisko tím, že „by na ni Státní zdravotni ústav nestačil vědeckou kapacitou ani dostatečným počtem schopných pedagogických sil““. ${ }^{16}$

Velkým propagátorem školy byl Hynek Pelc (1895-1942), profesor sociálního lékařství a ředitel SZÚ (1938-1939), který jako stážista RF absolvoval studijní pobyty na Harvardově univerzitě, v Cambridgi a na Univerzitě Johnse Hopkinse v Baltimoru, kde získal doktorát $\mathrm{z}$ veřejného zdravotnictví. Pelc se na základě svých zkušeností z anglosaského světa zaměřoval na prolínání hygienicko-epidemiologického př́stupu se sociálně-lékařským hlediskem, zaváděl do oboru statistické a sociologické metody a rozpracoval metodiku preventivní péče o kojence, děti a těhotné ženy. Ve veřejném zdravotnictví kladl důraz na prevenci a vysokou odbornost pracovníkủ, v nichž se snažil vyvolat zájem o modernizaci zdravotní výchovy a osvěty. ${ }^{17}$

Dříve než v Praze se naděje na založení nové školy vyskytla v roce 1925 v Brně, kde se lékařská fakulta již delší dobu pokoušela vytvořit ve spolupráci s ministerstvem zdravotnictví a Rockefellerovou nadací nový ústav amerického typu, jak o tom vypovídá dopis Hynka Pelce adresovaný Frances Crowellové. ${ }^{18}$ Ta se chopila př́ležitosti a pokoušela se uvést projekt do praxe. ${ }^{19}$ Plán však byl v roce 1929 vetován s tím, že lékařská fakulta se má primárně věnovat vědě, tedy medicíně, a nikoli ošetřovatelství; svou roli sehrála i námitka, že by absolventky takové školy nenašly uplatnění. Crowellová na to reagovala prohlášením, že mnoho uchazeček by raději šlo studovat ošetřovatelství než medicínu, kdyby prestiž povolání sestry vzrostla. ${ }^{20}$

Teprve pod vlivem debat o podobě vzdělávání na mezinárodních sjezdech v Bruselu ${ }^{21}$ a Pař́ži ${ }^{22}$ s ohledem na rezoluci II. sjezdu diplomovaných sester v Praze $^{23}$ a poté, co se lékaři a ošetřovatelky z Československa seznámili během studijních pobytů v USA s tak

15 Tamtéž, s. 22.

16 Tamtéž, s. 18.

17 Magdalena ČESNEKovÁ, MUDr. Hynek Pelc, profesor sociálního lékařství a ředitel Státního zdravotního ústavu, Praktický lékař 94/2, 2014, s. 99-101.

18 E. Vickers, Frances Elisabeth Crowell and the Politics of Nursing, s. 81-82 s odkazy na korespondenci Frances Crowellové, uloženou v Rockefeller Archive Center v New Yorku.

19 Z revidovaného ošetřovatelského programu RF z ledna 1928 je zřejmé, že záměrem nadace bylo vytvořit v Praze a Brně nový typ sociálně zdravotní školy, pokud o to místní úřady požádají, respektive umístit takovou školu, pokud by to bylo možné, jen na jednom místě. Srov. DME Nursing Programme (Revised January 1928), in: 100 Years: The Rockefeller Foundation [online], (C) The Rockefeller Archive Center. Dostupné z: <http:// rockefeller100.org/files/original/d2366beaed952cfd53ed18f6fb2dfd90.pdf > (6. 2. 2017).

20 E. Vickers, Frances Elisabeth Crowell and the Politics of Nursing, s. 86 s odkazy na korespondenci Frances Crowellové, uloženou v Rockefeller Archive Center v New Yorku.

21 Josefa FiLIPOVÁ, Ošetřovatelství na mezinárodní konferenci v Bruselu, Zprávy ČSČK 10, 1930, s. 157-158.

22 Julie MolnáRovÁ, Mezinárodni kongres sester ošetřovatelek, ČN 3, 1933, s. 251-253.

23 AHMP, fond Spolek diplomovaných sester, k. 69; srov. též Sborník II. sjezdu diplomovaných sester ošetřovatelekv ČSR, Praha 1932. 
zvanou epidemiologickou metodou, ${ }^{24}$ se podařilo ve vládě za vydatné pomoci Alice Masarykové založení nové školy prosadit.

Škola byla formálně zřízena na základě usnesení vlády ČSR ze dne 26. zář́i 1930 ministerstvem veřejného zdravotnictví a tělesné výchovy za součinnosti RF a ministerstva sociální péče. V reakci na to správa nadačního fondu RF schválila dne 10. prosince 1930 finanční podporu ve výši 100000 USD na stavbu a vybavení školy a 25000 USD na provoz. Škola však byla otevřena až v únoru 1936. Po vzniku Protektorátu Čechy a Morava byl kontakt školy s RF přerušen a na doporučení Frances Crowellové nepodporovat protektorátní vládu zůstala poslední částka ve výši 6700 USD nevyplacena. ${ }^{25}$

Správu školy ř́idilo kuratorium, které se skládalo ze dvou zástupců z každého ze tř́i ministerstev (ministerstvo veřejného zdravotnictví a tělesné výchovy, ministerstvo sociální péče a ministerstvo školství a národní osvěty) s hlasem rozhodujícím a z ředitelky školy a její zástupkyně s hlasem poradním. Řízení školy třemi subjekty bylo podrobováno kritice, protože všechna jednání a rozhodování byla zdlouhavá a nepružná. Kuratorium rozhodovalo o správě rozpočtu, př́ípravě statutu školy a jejích osnov, o obsazování učitelských míst a o prijijímání a propouštění studentek. ${ }^{26}$

Výuka začala 15. února 1936, škola však byla slavnostně otevřena až 7. března 1936 u př́ležitosti 86. narozenin T. G. Masaryka, a to pod názvem „Masarykova státní škola zdravotní a sociální péče“. ${ }^{27}$ Proti původním plánům RF se ji nepodařilo institucionálně propojit ani se SZÚ, ani s univerzitou. Škola byla určena pro absolventky středních škol.

Theodor Gruschka, přední znalec v oboru hygieny, který se společně s ministrem zdravotnictví Ludwigem Czechem podílel na prípravě koncepce školy, kladl na budoucí sociálně-zdravotní pracovnice enormní nároky. Jejich úkolem v nemocnici mělo být získávat informace o pacientovi a jeho sociálních poměrech, sdělovat poznatky lékaře nemocným, bojovat $\mathrm{v}$ rámci edukace proti předsudkům a pověrám a organizovat materiální pomoc jedincům v nouzi. Možnosti uplatnění absolventek se mimo nemocnice měly rozšířit i na místa ve speciálních léčebných ústavech, ozdravovnách, sanatoriích a lázních; působit měly rovněž v úřadovnách sociální a zdravotní péče, $\mathrm{v}$ preventivních poradnách všeho druhu, v humanitních a sociálních zařízeních (jesle, denní útulky, sirotčince, chorobince a chudobince) a prostřednictvím následné péče zajišt'ovat dohled nad nemocným po propuštění $\mathrm{z}$ nemocnice. $\mathrm{V}$ rámci praktického výcviku se studentky měly $\mathrm{v}$ nemocnicích seznamovat $\mathrm{s}$ dokumentací pacienta a měly při vizitách referovat o svých zjištěních. Studentka musela zvládnout základní péči o nemocného, asistenci při vyšetřování, antropometrická měření, laboratorní vyšetření, dezinfekci, péči o ženu před porodem a po něm, péči o kojence, př́pravu základních diet, fototerapii, obvazovou techniku a první pomoc, léčebný tělocvik a masáže. ${ }^{28}$

První roky existence školy provázely spory se stoupenci dominantní pozice sociální péče ve výuce, kteř́ usilovali o to, aby škola spadala pod ministerstvo sociální péče. Přestože byl

24 Hazel A. GoFf, Ošetřovatelství v Československu, ČN 4, 1934, s. 243-247.

25 Rockefeller Archive Center (dále RAC), fond Rockefeller Foundation (FA 395), field offices, Paris, RG 6, SG 1, k. 20, složka 218 IHD - Czechoslovakia, Prague School for Nurses in Public Health and Social Medicine, 1937-1939, dopis F. E. Crowellové A. J. Warrenovi, 21. 8. 1939.

26 Národní archiv (dále NA), fond Ministerstvo sociální a zdravotní správy, k. 7, i. č. 15, sign. A 3111, schůze kuratoria MSŠZSP, návrh organizačního statutu školy, dohodnutý na poradě konané 23. 8. - 24. 8. 1935, bod I.

27 Archiv Kanceláře prezidenta republiky, fond Alice Masaryková, k. 304.

28 Theodor GruschKA, O výcviku sociálnich sester v nemocnici, ČN 6, 1936, s. 127-132. 
koncept nové školy dlouho projednáván, stále se nedařilo dosáhnout shody mezi představami zástupců státu a RF v otázce profilu absolventek. Zatímco ze strany československých odborníků podporovaných Alicí Masarykovou měla být cílem výchova sociálních pracovnic s kompetencemi v oblasti ošetřovatelství, a v tomto smyslu byla nová škola chápána spíše jako náhrada za zaniklou Vyšší školu sociální péče, ze strany RF mělo jít naopak o školu, která by primárně vychovávala ošetřovatelky s kompetencemi v oblasti sociální péče.

Při projednávání obsahové náplně vyvstaly problémy ve vzájemné komunikaci mezi ředitelkou školy Amálií Houžvicovou, jež hájila představy zástupců RF preferující zdravotní zaměření výuky, a ministrem Ludwigem Czechem, který kladl důraz na vzdělávání v oblasti sociální péče. Diskuse nad profilem absolventek školy přiměly ministra Czecha $\mathrm{k}$ rozširření hodinové dotace ošetřovatelských předmětů a ke změně oficiálního názvu školy na „Masarykova státní škola zdravotní a sociální péče pro výchovu sociálně-zdravotních pracovnic“, s nímž RF projevila souhlas ${ }^{29}$ nebot' ,plně garantoval ženský charakter školy a jejího poslání ve vzdèláváni personálu, který méla RF na mysli od počátku finanční podpory poskytnuté na zř́zení školy“.30

Jiným zásahem ministra Czecha do struktury školy bylo její rozšíření o německé oddělení, s nímž RF původně nepočítala. Czech je zř́idil o vlastní vůli proto, že těžce nesl, že do stávající školy pro sociální pracovnice v Liberci (Bildungsanstalt für sozial-pädagogische Frauenberufe $)^{31}$ nebyly přijímány žačky z židovských a sociálnědemokratických rodin. ${ }^{32}$ Ministr chtěl $\mathrm{z}$ tohoto oddělení $\mathrm{v}$ budoucnu vybudovat samostatnou německou státní sociálně-zdravotní školu s cílem vychovat z německých posluchaček občanky, které by byly loajální k Československé republice. $Z$ tohoto důvodu přijímal do školy nový německý personál. Tento plán však ztroskotal. Náklady na vydržování německého oddělení byly kvůli malému počtu německých posluchaček s maturitou př́iliš vysoké. Státní správa doplácela na honoráŕích přednášejícím za každou českou posluchačku asi 1650 Kč, za německou 4350 Kč. ${ }^{33}$ Czech to řešil tak, že přijímal proti vůli Houžvicové i některé žadatelky bez maturity, které však ve škole těžce zápasily s komplexem méněcennosti nebo školu záhy opouštěly. Aby se počet posluchaček německého oddělení vůbec naplnil, byly do něj posílány i některé české žadatelky znalé němčiny. ${ }^{34}$

Neshody mezi ministrem a ředitelkou přetrvávaly až do dubna 1938, kdy byl Ludwig Czech jako německý sociálnědemokratický politik židovského původu přinucen ministerstvo opustit. O těchto sporech jsme informováni výhradně ze soukromé korespondence Amálie Houžvicové s Frances Crowellovou, která byla pro ředitelku důležitou oporou. Houžvicová jí v důvěrném dopisu z 18. dubna 1937 psala o neuspokojivých pracovních

29 NA, fond Ministerstvo sociální a zdravotní správy, k. 7, i. č. 15, sign. A 3111, schůze kuratoria MSŠZSP, 25.1. 1937; RAC, f. Rockefeller Foundation (FA 395), field offices, Paris, RG 6, SG 1, k. 20, složka 218 IHD Czechoslovakia, Prague School for Nurses in Public Health and Social Medicine, 1937-1939, dopis Ludwiga Czecha Frances Crowellové, 24. 3. 1937.

30 RAC, f. Rockefeller Foundation (FA 395), field offices, Paris, RG 6, SG 1, k. 20, složka 218 IHD - Czechoslovakia, Prague School for Nurses in Public Health and Social Medicine, 1937-1939, dopis George K. Strodeho ministru Františku Ježkovi, 10. 6. 1938.

31 K historii liberecké školy srov. Peter Reinicke, Reichenberg (Sudetengau), in: Die Ausbildungsstätten der sozialen Arbeit in Deutschland 1899-1945, Freiburg im Br. 2012, s. 364-366.

32 NA, fond Ministerstvo sociální a zdravotní správy, k. 8, i. č. 18, sign. A 3118, informace pro ministra, 11. 7. 1939.

33 Tamtéž, informace pro ministra, 19. 8. 1939.

34 NA, f. Ministerstvo sociální a zdravotní správy, k. 8, inv. č. 17, sign. A 3116, rozpočtové a účetní záležitosti MSŠZSP, zpráva Amálie Houžvicové pro ministerstvo sociální a zdravotní správy, 16. 8. 1939. 
podmínkách ve správě školy a svěřovala se jí, že Ludwig Czech svými despotickými nařízeními brání realizaci jejích dobře míněných záměrů. ${ }^{35}$ Jako ředitelka nemohla o vedení školy samostatně rozhodovat. Lepší vzájemné komunikaci neprospíval ani fakt, že RF pro ni byla větší autoritou než ministr, a proto místo s ním konzultovala každou záležitost s evropskou divizí nadace. Navíc její finanční podmínky byly neuspokojivé. Původně jí byl přislíben plat ve čtvrté stupnici pro státní zaměstnance ve výši 36000 Kč ročně, ten jí však byl o 3000 Kč zkrácen, a stejně tak nedostala slibovanou definitivu, respektive desetiletou smlouvu s pravidelným navyšováním platu každé tři roky. Jediné, co jí ministerstvo nabídlo, byla smlouva na tři roky. ${ }^{36}$ Houžvicová se tak dostala do nevýhodné pozice; během své předchozí kariéry totiž na tom byla jako lékařka na Podkarpatské Rusi finančně lépe. ${ }^{37}$

Všechny tyto důvody vedly Amálii Houžvicovou k zvažování odchodu ze školy. V jejích úvahách o potenciálním nástupci figuroval Bohumil Vacek, kterému v roce 1937 končila lhůta pro výkon funkce ředitele SZÚ, ale tato představa byla pro vedení RF nepřijatelná, protože ve smlouvách, které nadace uzavírala s vládami jednotlivých států, bylo výslovně uvedeno, že školu musí řídit sestra. Měla-li Houžvicová školu dále vést, bylo nutné, aby absolvovala studium ošetřovatelství ve Spojených státech. ${ }^{38}$ To se týkalo i její zástupkyně, doktorky medicíny a filozofie Gertrudy Jedličkové, která byla pověřena řízením výuky v německém oddělení. Přes časté naléhání ze strany zástupců nadace však nebyla ani jedna z nich ke studiu v USA uvolněna. Nejdříve tomu bránilo pracovní vytížení ve škole, později zrušení německého oddělení a politicky nestabilní situace, která donutila Gertrudu Jedličkovou k 15. únoru 1939 ze školy odejít. ${ }^{39}$

Výrazem napjatých vztahů mezi ministrem a ředitelkou byla i ta okolnost, že když v lednu 1938 Ludwig Czech zř́́dil na ministerstvu zdravotnictví ošetřovatelský odbor, do něhož jmenoval kromě ministerských úředníků také ředitele ošetřovatelských škol, Houžvicová přizvána nebyla. Tyto okolnosti vedly Frances Crowellovou k zaslání stížnosti ministrovi, která ovšem zůstala bez odpovědi, a proto se R. M. Taylor, ředitel SZÚ v Budapešti, rozhodl řešit situaci osobní návštěvou. ${ }^{40}$

Určitá naděje na to, že Amálie Houžvicová bude moci svoje záměry prosadit, přišla až poté, co Ludwiga Czecha (4. června 1935 - 11. dubna 1938) vystřídal na pozici ministra František Ježek (10. května 1938 - 22. záŕí 1938), který na rozdíl od svého předchůdce do ošetřovatelské problematiky nezasahoval. ${ }^{41}$ Zdálo se, že vstřícná Marta Johanovská, která měla na ministerstvu $\mathrm{v}$ referátu ošetřovatelské školy a byla záhy po výměně ministrů jmenována jako první žena $\mathrm{v}$ zemi do pozice ministerského rady, bude mít více pravomoci

35 RAC, f. Rockefeller Foundation (FA 395), field offices, Paris, RG 6, SG 1, k. 20, složka 218 IHD - Czechoslovakia, Prague School for Nurses in Public Health and Social Medicine, 1937-1939, dopis Amálie Houžvicové Frances Crowellové, 18. 4. 1937.

36 Tamtéž, deník Frances Crowellové, 21. 12. 1937.

37 Tamtéž, dopis Amálie Houžvicové Frances Crowellové, 18. 4. 1937. Houžvicová působila před nástupem na Masarykovu státní školu jako lékařka v Lisičevu na Podkarpatské Rusi. Srov. adresár pro Podkarpatskou Rus Z roku 1925, dostupné z: <http://genealogyindexer.org/view/1925CarpRuth/1925CarpRuth\%20-\%200021.pdf> (6. 2. 2017).

38 Tamtéž, deník Frances Crowellové, 21. 12. 1937.

39 Tamtéž, dopis Marty Johanovské Frances Crowellové, 23. 8. 1938, a dopis Amálie Houžvicové Frances Crowellové, 14. 12. 1938

40 Tamtéž, dopis Frances Crowellové ministru Ludwigu Czechovi, 6. 1. 1938, a dopis R. M. Taylora F. Crowellové, 14. 1. 1938.

41 Tamtéž, deník Frances Crowellové, 11. 5. 1938. 
k tomu, aby pomohla plány Houžvicové naplnit. ${ }^{42}$ Spokojenost s novými personálními změnami na ministerstvu vyslovila i Frances Crowellová, zejména poté, co se ministr Ježek ohradil proti plánu pražského magistrátu zř́idit pod tlakem hrozící války vlastní školu sociální péče s tím, že stávající Masarykova státní škola bude sloužit k výchově nemocničních sester. Ježek argumentoval tím, že nové ošetřovatelské školy jistě vznikat mohou, ale že Masarykova škola zůstane státní školou vychovávající typ sociálně-zdravotní sestry. ${ }^{43}$

Špatná komunikace mezi ředitelkou a ministrem, která znemožňovala řešit dílčí aktuální problémy, však měla největší dopad na samotné studentky. Přetížení v důsledku neobyčejně ambiciózního studijního programu a nejasnosti v otázce profilu absolventek je vedly ke zformulování protestu a předložení požadavků na řešení nejpalčivějších problémů: 1. neprodlužovat neočekávaně dobu studia, nebot’ rodiče byli připraveni hradit školu jen dva roky, jak jim to bylo původně oznámeno; v budoucnu prodloužit výuku na tři roky, aby se studentky mohly adekvátně připravit ke zkouškám; 2 . ukončit blokovou výuku každého předmětu okamžitou zkouškou, nenechávat ji až na závěr studia; 3 . důsledně dodržovat požadavek maturity jako podmínku přijetí na školu; 4. lépe školu propagovat; 5. rozšiřrit osnovy o práci s rentgenem a rehabilitační tělocvik. ${ }^{44}$

Ředitelka školy studentky podpořila a $\mathrm{k}$ jejich protestu připojila ještě další návrh, aby se v budoucnu řešila otázka postavení školy ve školském systému, nebot' stojí rozkročena mezi střední a vysokou školou. Studentky touto peticí prokázaly, že si za svou školou stojí a že chtějí udržet její vysokou úroveň, což s povděkem kvitovaly jak Houžvicová, tak Crowellová. ${ }^{45}$ Jejich iniciativa byla o to významnější, že v té době bylo ještě mezi lékaři a ministerskými úředníky nemálo těch, kteři ji považovali spíše za experiment s nejistým výsledkem.

Reakce Ludwiga Czecha byla popudlivá: RF mu prý svazuje ruce. K prvnímu bodu uvedl, že stávající osnovy považuje za minimální a že požadavky do budoucna naopak ještě vzrostou; $\mathrm{k}$ požadavku prodloužit studium na tři roky, jak to $\mathrm{v}$ té době už bylo na mnoha školách tohoto typu ve světě obvyklé, se však nevyjádřil. Ke třetímu bodu vysvětlil, co ho k porušování nastavených podmínek přijetí na školu vede: nechce znemožnit studium dívkám z chudých rodin; bylo by to podle jeho názoru nesociální. Ostatní požadavky akceptoval. ${ }^{46}$

Uvedené skutečnosti svědčí o neujasněné koncepci školy. Kvưli náročnému kurikulu se délka výuky během studia postupně prodlužovala ze dvou na více než dva a půl roku, konkrétně z původně plánovaného počtu 22,5 měsíců pro výuku a praxi ${ }^{47}$ na $24,{ }^{48}$ respektive 27,5 měsíců v roce $1937^{49}$ a dále až na 29 měsícủ v roce 1938.50

42 Tamtéž, deník Frances Crowellové, 2. 7. 1938.

43 Tamtéž.

44 Tamtéž, deník Frances Crowellové, 1. 5. 1937.

45 Tamtéź.

46 NA, f. Ministerstvo sociální a zdravotní správy, k. 7, i. č. 15, sign. A 3111, schůze kuratoria MSŠZSP, 21. 6. 1937.

47 Tamtéž, návrh organizačního statutu MSŠZSP, dohodnutý na poradě konané 23.-24. 8. 1935.

48 Tamtéž, schůze kuratoria MSŠZSP, 14. 12. 1936.

49 Muzeum Komenského Přerov, i. č. 1473/74/1, sign. VZ 752, Masarykova státní škola zdravotní a sociální péče. Praha b. 1., informační leták školy s osnovou výuky pro školní rok 1937-1938.

50 NA, f. Ministerstvo sociální a zdravotní správy, k. 7, i. č. 15, sign. A 3111, schůze kuratoria MSŠZSP, 25. 4. 1938. 
Studium se skládalo z teoretických přednášek a nemocniční praxe a bylo rozděleno do tř́ období. V souvislosti s rozhodnutím prodloužit studium, které se vztahovalo i na stávající, již otevřený ročník, se proměňovala i podoba kurikula. Po úpravách osnov z roku 1935, jež se týkaly zejména hodinové dotace, vypadala výuka nově přijatých studentek v letech 1937-1939 následovně: k profilovým předmětům prvního běhu patřila hygiena, bakteriologie a epidemiologie (60 hodin) na jedné straně a sociologie na straně druhé (60 hodin). Zatímco v prvním běhu byl poměr hodin zdravotnického a sociálního zaměření vyrovnaný, ve druhém běhu převažovaly přednášky z veřejné správy (74 hodin), sociálního pojištění (60 hodin) a občanského práva (60 hodin), ze zdravotnických předmětů bylo nejvíc prostoru vyhrazeno internímu lékařství (33 hodin) a farmakologii (33 hodin). Ve třetím běhu se kladl hlavní důraz na teorii př́padové práce ( 97 hodin), v němž studentky procvičovaly holistický př́stup v modelových situacích. V posledním běhu měly př́iležitost seznámit se se základy žurnalistiky a prezentace vlastní profese.$^{51} \mathrm{Z}$ celkové struktury výuky je zřejmé, že profil absolventek byl velmi široký a to kladlo na studentky vysoké nároky. Šlo vskutku o impozantní rozsah, který z absolventek vychoval ojedinělé odbornice.

Masarykova státní škola se od ostatních ošetřovatelských škol lišila větším dưrazem na výuku veřejného zdravotnictví a zároveň větším zaměřením na praxi prováděnou jak v nemocnicích, tak i v dalších zdravotnických a sociálních institucích. Terénnímu výcviku bylo v rámci studia vyhrazeno celkem 504 dní. Zatímco na běžných ošetřovatelských školách byl poměr teorie a praxe zhruba $60: 40$, z hodinové dotace jednotlivých předmětů je zřejmé, že zde tomu bylo v souladu s požadavky RF právě naopak. Praxe zabírala 44 hodin týdně a teorii bylo vyhrazeno 32 hodin týdně. Šlo tedy celkem o 76 hodin týdně.

Podle původních představ mělo zatížení studentek odpovídat poměrům na jiných středních školách. Praktické přednášky se měly konat $\mathrm{v}$ čase od 8:00 do 13:00 a praktická cvičení v odpoledních hodinách. ${ }^{52}$ Po navýšení obsahové náplně výuky v roce 1937 však zátěž studentek v rámci bloků enormně narostla. Studentky byly přetížené, a nepřekvapí proto, že si ředitelka školy stěžovala zástupcům RF na mnoho hodin praxe. Frances Crowellová však na 44 hodinách praxe v nemocnici po dobu 40 týdnů trvala. ${ }^{53}$

Výukou na Masarykově státní škole byli pověřeni přední odborníci z řad českých a německých profesorů a docentů Lékařské, Právnické a Filozofické fakulty Univerzity Karlovy a významní úředníci ministerstev. Mnozí z učitelů patřili mezi zakladatele přednášených vědních oborů $\mathrm{v}$ Československu, nebo se př́mo podíleli na tvorbě zdravotní a sociální politiky a jejích legislativních opor. Přednášky z anatomie zajištovala $\mathrm{v}$ českém oddělení ředitelka školy Amálie Houžvicová, v německém její zástupkyně Gertruda Jedličková. Ostatní vyučující se jako externisté střídali.

Profilové předměty z veřejného zdravotnictví v českém jazyce učili vesměs pracovníci SZÚ. Na výuce hygieny, epidemiologie a bakteriologie se v prvním běhu podílel Jaroslav Klíma, přednosta oddělení pro sociální hygienu SZÚ, sociální lékařství přednášel Hynek Pelc. $Z$ dalších pracovníků ústavu byli do výuky zapojeni Ludmila Mlčochová, zástupkyně

51 Muzeum Komenského Přerov, i. č. 1473/74/1, sign. VZ 752, Masarykova státní škola zdravotni a sociální péče. Praha b. 1., informační leták školy s osnovou výuky pro školní rok 1937-1938.

52 NA, f. Ministerstvo sociální a zdravotní správy, k. 7, i. č. 15, sign. A 3111, informace pro ministra, 23. 10.1935.

53 RAC, f. Rockefeller Foundation (FA 395), field offices, Paris, RG 6, SG 1, k. 20, složka 218 IHD - Czechoslovakia, Prague School for Nurses in Public Health and Social Medicine, 1937-1939, deník Frances Crowellové, 18. 3. 1937 . 
přednosty oddělení pro výrobu léčivých sér a očkovacích látek SZÚ, Otto Schubert, přednosta oddělení pro biologickou kontrolu léčiv SZÚ, a Marie Podzimková-Rieglová, která sestavila pro studentky sylabus přednášek o dietetice a s Hynkem Pelcem vydala v roce 1934 populární pojednání o bramborách. ${ }^{54}$ Výuku sociologie jako druhého profilového předmětu prvního běhu zajišt’oval Otakar Machotka, přední český sociolog, průkopník sociologie rodiny a zakladatel první manželské poradny v Praze.

Ke stěžejním oporám školy v učitelském sboru patřili Václav Prošek a Theodor Gruschka. Oba vedli sociálně zdravotní seminář ve druhém a případové práce ve třetím běhu a oba rovněž předsedali zkušebním komisím: Prošek v českých a Gruschka v německých třídách. ${ }^{55}$ Pediatr Václav Prošek (1894-1978) řídil na pražském magistrátu jako zdravotní rada odbor sociální hygieny a odbor školního lékařství a zdravotnictví. Jako docent působil rovněž v Ústavu pro sexuální patologii, založeném v roce 1921 jako první univerzitní pracoviště na světě. ${ }^{56}$

Theodor Gruschka (1888-1967) byl oceňován jako výborný přednášející, který měl bohaté zkušenosti ze své praxe v Ústí nad Labem, kde se jako městský lékař zasloužil o modernizaci tamní nemocnice. Jeho odborný zájem se soustředil na problematiku tuberkulózy, alkoholismu a pohlavních chorob, na hygienu bydlení, zásobování vodou a nemocniční ústavnictví. $Z$ těchto oblastí publikoval řadu odborných prací a ve třicátých letech přednášel hygienu také na Německé univerzitě v Praze. Byl blízkým spolupracovníkem Ludwiga Czecha (1870-1942), který ho v roce 1937 povolal na ministerstvo zdravotnictví. Spolu s ním a lékařem Arnoldem Holitscherem (1859-1942) byl Gruschka činný ve Spolku německých sociálnědemokratických lékařů v ČSR (Verein der deutschen sozialdemokratischen Ärzte in der Čechoslovakischen Republik) a v Mezinárodním sdružení socialistických lékařù (Internationale Vereinigung sozialistischer Ärzte), založeném Czechem v roce 1931 v Karlových Varech. Kromě výše zmíněných předmětů Gruschka na škole přednášel také sociální lékařství a nemocenské pojištění. ${ }^{57}$

Organizace výuky měla vysokoškolský charakter: teoretické předměty přednášeli profesoři a docenti a cvičení vedly instruktorky. V prvním školním roce na škole jako instruktorky působily učitelky pražské ošetřovatelské školy Jarmila Roušarová, Anna Marie Šindlerová a Františka Růžičková, které kromě ošetřovatelských předmětů vedly laboratorní cvičení (Šindlerová) a praktika ze všeobecné hygieny (Šindlerová), anatomie (Roušarová), fyziologie (Růžičková), psychologie a pedagogiky (Roušarová), sociologie (Roušarová) a sociálního pojištění (Šindlerová). ${ }^{58}$ Způsobem výuky se Masarykova státní škola odlišovala od zavedené organizace na běžných ošetřovatelských školách, kde lékařské předměty učili pouze lékaři. Díky tomu, že praktický výcvik v lékařských oborech zajišt'ovaly instruktorky, měla výuka blíž k požadované praxi.

Jarmila Roušarová a Anna Marie Šindlerová byly na škole zaměstnány pouze jeden rok. K 1. lednu 1937 byly místo nich prrijaty pro cvičení v sociálních oborech dvě sociální instruktorky Marie Czerná-Rosenbergová a Jindřiška Cellerová. Od stejného data vedla

54 Hynek Pelc - Marie Podzimková-RieglovÁ, Brambory - obrana proti kurdějím, Praha 1934 (zvláštní otisk z časopisu Hygiena 7/8-9, 1934).

55 NA, f. Ministerstvo sociální a zdravotní správy, k. 7, i. č. 15, sign. A 3111, schůze kuratoria MSŠZSP, 21. 3. 1938.

56 NA, f. Ministerstvo sociální a zdravotní správy, k. 7, i. č. 16, sign. A 3112, učitelský sbor MSŠZSP.

57 Tamtéž; srov. též M. Vamberová, Prof. MUDr. Theodor Gruschka, s. 72-73.

58 AHMP, f. Masarykova státní škola zdravotní a sociální péče, tř́́dní kniha, 1936-1937. 
výuku na chirurgii ve Vinohradské nemocnici kromě Františky Růžičkové také zdravotní instruktorka Marie Uhlíková, kterou si Crowellová velmi pochvalovala pro její dobrý vztah s ř́ádovými sestrami a považovala ji celkově za lepší instruktorku než Roušarovou a Šindlerovou. ${ }^{59}$ Jak Růžičková, tak Uhlíková absolvovaly studijní stáže ve Spojených státech, které byly hrazeny z prostředků RF. V německém oddělení působila jako zdravotní instruktorka diplomovaná sestra Hilde Wernerová a v zář́i 1937 byly príijaty další dvě diplomované sestry z Brna: Marie Vystavilová pro české a Ema Schönová pro německé oddělení. ${ }^{60}$ Početní stav instruktorek se neustále navyšoval. Ve školním roce 1937-1938 jich bylo ve škole zaměstnáno celkem devět, z toho šest zdravotních a tři sociální, ${ }^{61}$ a v rozpočtu na rok 1939 se už počítalo s dvanácti instruktorkami. ${ }^{62}$ Není pochyb o tom, že vy̌̌ší profesní odbornost těchto instruktorek vedla ke zkvalitnění výuky, a to i přesto, že Organizace sociálních pracovnic, sdružení absolventek Vyšší školy sociální péče, se proti převaze zdravotních instruktorek ostře ohradila. ${ }^{63}$

Mezi učiteli se vystřídala celá plejáda významných osobností, které škole zaručovaly vysoký kredit. Českým posluchačkám mezi jinými přednášeli fyziolog František Karásek (1902-1979), pediatr Josef Švejcar (1897-1997), Jaroslav Procházka (1896-1967), zakladatel oboru infekční lékařství, Jaroslav Teisinger (1902-1985), zakladatel oboru pracovní lékařství, psycholog Cyril Stejskal (1890-1969), právnička Jarmila Veselá (1899-1972), novináŕ, editor a husitský teolog František Kovář (1888-1969) a Josef a Marie Krakešovi, teoretici sociální práce v ČSR; v německém oddělení vyučoval epidemiolog Ernst Singer (1899-?), pediatr Berthold Epstein (1890-1962), filozof, estetik a psycholog Emil Utitz (1883-1956), psycholog Franz Scola (1899-1945), právníci Robert Neuner (1878-1945) a Edgar Maria Foltin (1897-1974), statistici Franz Xaver Weiss (1885-1956), Josef Fuhrich (1897-1945) a řada dalších. ${ }^{64}$

Do školy byly přijímány absolventky všech typů středních škol s maturitou ve věku od osmnácti do třiceti let. Výjimečně mohly být přijaty uchazečky bez středoškolského vzdělání, pokud se prokázaly nejméně dvouletou praxí ve zdravotních nebo sociálních institucích ${ }^{65}$ Do počátku druhé světové války byly na Masarykově státní škole otevřeny celkem tři ročníky: první v únoru 1936, druhý v záŕí 1937 a třetí v září 1938. Počet studentek přijatých $\mathrm{v}$ jednom roce do obou oddělení se pohyboval mezi čtyřiceti osmi a padesáti dvěma:

59 RAC, f. Rockefeller Foundation (FA 395), field offices, Paris, RG 6, SG 1, k. 20, složka 218 - IHD Czechoslovakia, Prague School for Nurses in Public Health and Social Medicine, 1937-1939, deník Frances Crowellové, 19. 3. 1937.

60 NA, f. Ministerstvo sociální a zdravotní správy, k. 7, i. č. 15, sign. A 3111, schůze kuratoria MSŠZSP, 25. 1.1937.

61 NA, f. Ministerstvo veřejného zdravotnictví a tělesné výchovy, k. 534, dopis členek Organizace sociálních pracovnic ministerstvu zdravotnictví, 28. 3. 1938; Muzeum Komenského Přerov, i. č. 1473/74/1, sign. VZ 752, Masarykova státni škola zdravotni a sociálni péče. Praha b. 1., informační leták školy s osnovou výuky pro školní rok 1937-1938. Srov. též Pavla Kodymová, Historie české sociální práce v letech 1918-1948, Praha 2013, s. 83-84.

62 NA, f. Ministerstvo sociální a zdravotní správy, k. 8, i. č. 17, sign. A 3116, rozpočet MSŠZSP na rok 1939.

63 NA, f. Ministerstvo veřejného zdravotnictví a tělesné výchovy, k. 534, dopis členek Organizace sociálních pracovnic ministerstvu zdravotnictví, 28. 3. 1938.

64 NA, f. Ministerstvo sociální a zdravotní správy, k. 7, i. č. 16, sign. A 3112, učitelský sbor MSŠZSP; AHMP, f. Masarykova státní škola zdravotní a sociální péče, tř́ídní knihy a katalogy, 1936-1939; Zdravotnická ročenka československá 1938, ed. Jiří ŘíHA, Praha 1938.

65 Muzeum Komenského Přerov, i. č. 1473/74/1, sign. VZ 752, Masarykova státní škola zdravotní a sociální péče, Praha b. 1., informační leták školy s osnovou výuky pro školní rok 1937-1938. 
čtyřicet osm v prvním běhu (únor 1936 - květen 1938), čtyřicet devět v druhém běhu (září 1937 - prosinec 1939) a padesát dva v třetím běhu (září 1938 - květen 1941). ${ }^{66}$

Provoz německého oddělení byl však naprosto nerentabilní. Německý běh měl jen čtrnáct absolventek z ročníku 1936; ročníky 1937 a 1938 studium nedokončily, jen z ročníku 1937 studia zanechalo dvanáct posluchaček a čtyři další přestoupily do českého běhu. Některé na studium nestačily, jiné byly nuceny odejít ze školy z politických důvodů. Pro tak malý počet studentek musela škola hradit mzdy téměř stejnému počtu německých instruktorek a honoráře německým učitelům, jaké měl český běh s více než dvojnásobným počtem absolventek (celkem 33 v květnu 1938). ${ }^{67}$ Německé oddělení bylo navíc zdrojem napětí ve škole: pod vlivem politických událostí docházelo v roce 1938 ke konfliktům mezi nacionálně orientovanými posluchačkami a studentkami židovského původu, což obě skupiny manifestovaly nošením šedých a bílých punčoch. ${ }^{68} \mathrm{~K} 30$. září 1938 bylo proto německé oddělení zrušeno a personál určený pro německý běh byl propuštěn. ${ }^{69}$

Studentky pocházely vesměs ze středostavovských rodin učitelů, úředníků, řemeslníků a obchodníků. Objevují se mezi nimi také dcery lékařů, a to zpravidla těch, kteří měli k ošetřovatelskému personálu pozitivní vztah a podporovali ho. Jednou z nich byla dcera Bohumila Vacka. ${ }^{70}$ Některé zájemkyně nejenže absolvovaly střední školu, ale měly za sebou i jeden až tři roky studia na vysoké škole. K nejnadanějším studentkám MSŠZSP patřila Zdenka Goldbachová, která v roce 1932 získala titul doktorky př́rodních věd. Jeden rok pak pracovala v nutriční laboratoři SZÚ, ale protože se zajímala o nemocniční sociální péči, přihlásila se na MSŠZSP, kterou úspěšně dokončila v květnu 1939. Poté byla zaměstnána jako demonstrátorka preventivní péče na kardiologické klinice Vinohradské nemocnice. Ředitelka Houžvicová ji zasvětila do ošetřovatelské práce na oddělení infekčních chorob, která byla v té době velmi zanedbaná, a doporučila ji Rockefellerově nadaci jako svou možnou nástupkyni a perspektivní stipendistku studijního pobytu v USA. Za stávající politické situace však byla naděje na získání stipendia mizivá. ${ }^{71}$

Škola se stala útočištěm pro dcery z pronásledovaných německých sociálnědemokratických a židovských rodin a z kruhů říšskoněmeckých a ruských emigrantů. Patřily mezi ně např́iklad Věra Okuněva a Marie Vasiljeva, dcery předních ruských byzantologů Nikolaje Vasiljeviče Okuněva a Alexandra Alexandroviče Vasiljeva, členů Kondakovova ústavu v Praze. ${ }^{72}$ Dramatické osudy provázely mnoho studentek z pronásledovaných židovských

66 NA, f. Ministerstvo sociální a zdravotní správy, k. 7, i. č. 15, sign. A 3111, schůze kuratoria MSŠZSP, 3. 2. 1936, 24. 7. 1937, 21. 7. 1938 a 22. 8. 1938.

67 NA, f. Ministerstvo sociální a zdravotní správy, k. 8, i. č. 18, sign. A 3118, informace pro ministra o německém oddělení MSŠZSP.

68 RAC, f. Rockefeller Foundation (FA 395), field offices, Paris, RG 6, SG 1, k. 20, složka 218 - IHD Czechoslovakia, Prague School for Nurses in Public Health and Social Medicine, 1937-1939, deník Frances Crowellové, 9. 5. 1938 a zpráva min. rady Marty Johanovské, 8. 7. 1938.

69 Tamtéž, dopis Amálie Houžvicové Frances Crowellové, 14. 12. 1938; NA, f. Ministerstvo veřejného zdravotnictví a tělesné výchovy, k. 319, zpráva o likvidaci německého oddělení MSŠZSP a výpovědi instruktorek německého běhu, 15. 10. 1938; NA, f. Ministerstvo sociální a zdravotní správy, k. 8, i. č. 18, sign. A 3118, zpráva Amálie Houžvicové ministerstvu sociální a zdravotní správy, 16. 8. 1939.

70 RAC, f. Rockefeller Foundation (FA 395), field offices, Paris, RG 6, SG 1, k. 20, složka 218 - IHD Czechoslovakia, Prague School for Nurses in Public Health and Social Medicine, 1937-1939, deník Frances Crowellové, 5. 7. 1938 .

71 Tamtéž, deník Frances Crowellové, 21. 1. 1939.

72 NA, f. Ministerstvo sociální a zdravotní správy, k. 7, i. č. 15, sign. A 3111, schůze kuratoria MSŠZSP, 3. 2. 1936. 
rodin. Byla mezi nimi i dcera Alfreda Löw-Beera, rakouského podnikatele, jehož rodina se výrazně podílela na průmyslovém rozvoji Moravy. Když byla nucena po anšlusu Rakouska v březnu 1938 přerušit studium na lékařské fakultě ve Vídni, kde složila první rigorózní zkoušku, našla jako zcela nemajetná na doporučení československého konzulátu ve Vídni útočiště na Masarykově státní škole v Praze. ${ }^{73}$ Je až s podivem, že jiná Židovka narozená ve Vídni, Gerta Luftschützová, se na škole udržela od 1. září 1938 až do 20. května 1940 a až tehdy ji musela opustit. ${ }^{74}$

Studium historie školy v období druhé světové války a po ní je úkolem budoucího bádání. V roce 1939 začal německý nacionálněsocialistický ošetřovatelský spolek Nationalsozialistische Volkswohlfahrt (NSV) jednat s protektorátní vládou o obnovení německé třídy pro výchovu sociálně zdravotních pracovnic. Výsledkem bylo zřízení ošetřovatelského semináře pod nacistickou kontrolou, který byl otevřen 1. září 1940 v budově Palaty v Praze. ${ }^{75}$ České oddělení školy, která označení Masarykova mohla znovu nést až po osvobození v roce 1945, nadále vedla Amálie Houžvicová, a to patrně až do reorganizace zdravotnického školství v roce 1953, kdy byla škola definitivně zrušena.

Masarykova státní škola zdravotní a sociální péče představovala ojedinělou instituci v kontextu ošetřovatelského školství v meziválečném Československu. Vnášela do domácích poměrů nový integrační pohled na úkoly a kompetence zdravotního a sociálního personálu, který u mnoha současníků nenacházel pochopení. Učitele a studentky navíc často spojovaly dramatické osudy vyvolané nástupem nacismu: válku bud' vůbec nepřežili, nebo se zachránili emigrací do zahraničí. A tak jen nepatrný zlomek z celkem asi 250 absolventek, které škola do konce války vychovala, se mohl po roce 1945 ke své práci v Československu vrátit.

Sociálně-zdravotní typ sestry v Československu nezdomácněl ani po válce; i nadále se vedly spory o to, zda školu chápat jako zdravotní či sociální. Přesto si tehdejší politici byli jejího významu vědomi. Svědčí o tom vyjádření komunistické poslankyně Anežky Hodinové-Spurné a na návrh její stranické kolegyně Marie Trojanové 19. března 1947 přijatá rezoluce Ústavodárného národního shromáždění, která požadovala, ,aby posluchačkám Masarykovy státní školy zdravotni a sociálni péče v Praze, zaměstnaným v ústavech národního zdraví, které budou převzaty nebo nově přijaty do veřejné služby, bylo jejich předběžné vzdělání (maturita a 2 1/2roční vzděláni na škole s úrovní vysokoškolskou) řádně zhodnoceno jejich zařazením do služební tř. Ic, presto, že tato škola není uznávána za školu vysokou". 76

73 Tamtéž, 22. 8. 1938 a 28. 8. 1938.

74 AHMP, f. Masarykova státní škola zdravotní a sociální péče, třídní katalog, 1939-1940.

75 Zápisy z jednání mezi protektorátní vládou a NSV z let 1939-1940 a vyjádření ministerstva sociální a zdravotní správy ze dne 27. 5. 1940. NA, f. Ministerstvo sociální a zdravotní správy, 1939-1944, složka Německý běh Masarykovy státní školy zdravotní a sociální péče.

76 Poslanecká sněmovna Parlamentu České republiky, Společná česko-slovenská digitální parlamentní knihovna, Ústavodárné Národní shromáždění Republiky československé 1946-1948, stenoprotokoly 41. schůze, část 14/14, 19. 3. 1947. Dostupné z: <http://www.psp.cz/eknih/1946uns/stenprot/041schuz/s041014.htm> (6. 2. 2017). 


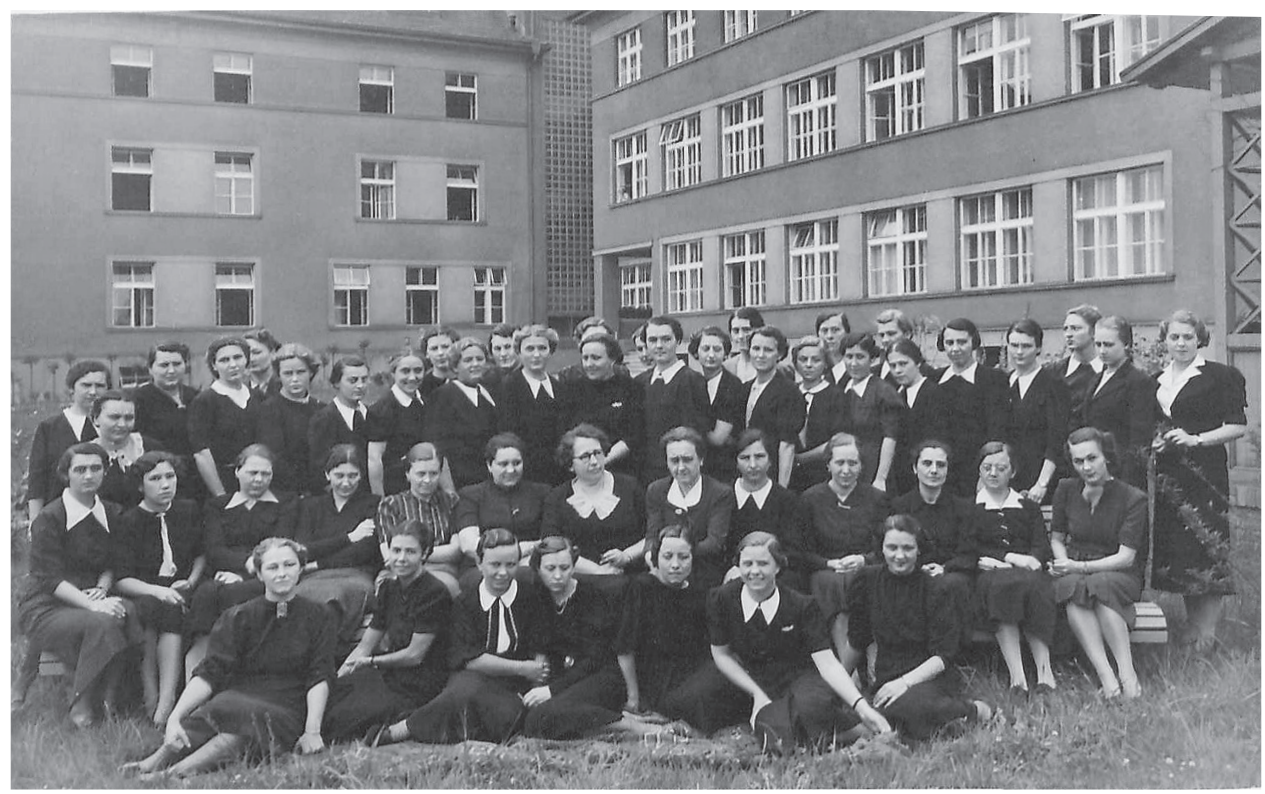

Obr. 1 První absolventky Masarykovy státní školy zdravotní a sociální péče, červen 1938 (uprostřed ředitelka MUDr. Amálie Houžvicová a její zástupkyně MUDr. PhDr. Gertruda Jedličková)

Zdroj Rockefeller Archive Center, New York, fond Rockefeller Foundation (FA 395), field offices, Paris, RG 6, SG 1, k. 20, složka 218 IHD - Czechoslovakia, Prague School for Nurses in Public Health and Social Medicine, 1937-1939

\section{Die Staatliche Masarykschule für Gesundheits- und Sozialfürsorge in der Zwischenkriegszeit}

\section{ZUSAMMENFASSUNG}

Die Staatliche Masarykschule für Gesundheits- und Sozialfürsorge, die beim Vinohrader Krankenhaus in Prag eingerichtet und von der Rockefeller-Stiftung finanziell unterstützt wurde, war eine einzigartige Einrichtung im Zusammenhang mit dem System der Fürsorgeschulen in der Tschechoslowakei der Zwischenkriegszeit. Sie trug in die einheimischen Verhältnisse einen integrativen Blick auf die Aufgaben und Kompetenzen des Gesundheitsund Fürsorgepersonals, was bei vielen Zeitgenossen auf kein Verständnis stieß. Ihr Ziel war es, den Typ einer hochqualifizierten medizinischen Sozialarbeiterin heranzuziehen, der in der Lage wäre, den heute wieder aktuellen holistischen Zugang zum Patienten voll zur Geltung zu bringen. Einen solchen Typ des Pflegepersonals gab es in der Tschechoslowakei nicht, denn die ersten Schulen für Pflegepersonal waren ausschließlich auf die Ausbildung von Krankenpflegerinnen ausgerichtet.

Formal wurde die Schule aufgrund eines Regierungserlasses vom 26. September 1930 durch das Ministerium für öffentliche Gesundheit und Körpererziehung unter Mitwirkung der Rockefeller-Stiftung und des Ministeriums 
für Sozialfürsorge eingerichtet, eröffnet wurde sie freilich erst am 15. Februar 1936. Gegen die Pläne der Rockefeller-Stiftung konnte sie sich institutionell weder mit dem Staatlichen Gesundheitsinstitut noch mit der Universität verbinden. Obwohl das Schulkonzept bereits seit Mitte der 1920er Jahre diskutiert wurde, unterschieden sich die Vorstellungen der staatlichen Vertreter und der Vertreter der Stiftung in der Frage des Absolventinnenprofils deutlich voneinander. Während seitens des tschechoslowakischen Fachpersonals, das von Alice Masaryk unterstützt wurde, das Ziel in der Ausbildung von Sozialarbeiterinnen mit Kompetenzen in der Krankenpflege bestand und in diesem Sinne die neue Schule als Ersatz für die nicht mehr existierende Höhere Schule für Sozialfürsorge fungierte, sollte es sich seitens der Rockefeller-Stiftung demgegenüber um eine Schule handeln, die primär Krankenpflegerinnen mit Kompetenzen im Bereich der Sozialfürsorge ausbilde.

Bei der Erörterung des inhaltlichen Aspekts entstanden Probleme in der gegenseitigen Kommunikation zwischen der Schuldirektorin Amalie Houžvicová, die die Vorstellungen der amerikanischen Seite verteidigte, und dem Gesundheitsminister Ludwig Czech, der den Nachdruck auf die Ausbildung im Bereich der Sozialfürsorge legte. Darüber hinaus erweiterte Minister Czech die Schule gegen den ursprünglichen Plan um eine deutsche Abteilung in dem Bemühen, die Diskriminierung von Schülerinnen aus jüdischen und sozialdemokratischen Familien, die in den dreißiger Jahren in den Grenzgebieten nicht in Fachschulen aufgenommen worden waren, zu kompensieren. Als deutscher sozialdemokratischer Politiker jüdischer Herkunft wollte er in der Zukunft eine selbstständige deutsche staatliche Schule für Sozialmedizin mit dem Ziel errichten, die deutschen Schülerinnen zu Bürgerinnen zu erziehen, die der Tschechoslowakischen Republik loyal gegenüberstünden. Dieser Plan scheiterte allerdings. Die Kosten für die Aufrechterhaltung der deutschen Abteilung waren angesichts der geringen Zahl deutscher Schülerinnen mit Abitur allzu hoch, weshalb die Abteilung am 30. September 1938 geschlossen wurde.

Die schlechte Kommunikation zwischen der Direktorin und dem Minister hatte die größten Auswirkungen auf die Schülerinnen selbst. Durch Überlastung infolge eines ungewöhnlich ambitiösen Ausbildungsprogrammes und durch Unklarheiten in der Frage des Profils der Schülerinnen sahen sich diese zur Abfassung eines Protests und zu Forderungen nach Lösung der dringendsten Probleme veranlasst. Wegen eines anspruchsvollen Curriculums wurde die Ausbildungszeit kontinuierlich von ursprünglich geplanten 22,5 Monaten pro Unterricht und Praxis im Jahre 1936 auf 29 Monate im Jahre 1938 verlängert.

Die Ausbildung setzte sich aus Theorie und Praxis zusammen und war in drei Durchgängen aufgeteilt. Zu den Profilfächern des ersten Durchgangs gehörten Hygiene, Bakteriologie und Epidemiologie (60 Stunden) einerseits und Soziologie andererseits (60 Stunden). Während im ersten Durchgang das Verhältnis zwischen der medizinischen und der sozialen Ausrichtung ausgeglichen war, überwog im zweiten Durchgang der Unterricht in öffentlicher Verwaltung (74 Stunden), in Sozialversicherung (60 Stunden) und in bürgerlichem Recht (60 Stunden). Von den medizinischen Fächern war der meiste Raum der inneren Medizin (33 Stunden) und der Pharmakologie (33 Stunden) vorbehalten. Im dritten Durchgang legte man den hauptsächlichen Nachdruck auf die Theorie von Fallbeispielen (97 Stunden), bei denen die Schülerinnen den holistischen Zugang in Modellsituationen übten. Am Ende der Ausbildung hatten sie die Möglichkeit, sich mit den Grundsätzen der Journalistik und mit der Präsentation ihres Berufes bekanntzumachen. Es handelte sich in der Tat um einen eindrucksvollen Umfang, in welchem die Schülerinnen zu einzigartigen Fachkräften ausgebildet wurden.

Die Staatliche Masarykschule unterschied sich von den übrigen Fürsorgeschulen durch einen größeren Nachdruck auf den Unterricht im öffentlichen Gesundheitswesen und gleichzeitig durch eine breitere Ausrichtung auf die sowohl in Krankenhäusern als auch in weiteren medizinischen und sozialen Einrichtungen geübte Praxis. Übungen im „Terrain“ waren im Rahmen der Ausbildung insgesamt 504 Tagen vorbehalten. Während das Verhältnis von Theorie und Praxis in den normalen Fürsorgeschulen 60:40 betrug, ist aus der Stundenzuwendung für die einzelnen Fächer ersichtlich, dass hier in Übereinstimmung mit den Forderungen der Rockefeller-Stiftung das genaue Gegenteil der Fall war: die Praxis beanspruchte 44 Wochenstunden, für die Theorie waren 32 Stunden pro Woche reseviert.

Mit dem Unterricht an der Schule waren führende Fachkräfte des Staatlichen Gesundheitsinstituts, tschechische und deutsche Professoren und Dozenten der medizinischen, juristischen und philosophischen Fakultät der Karlsuniversität und bedeutende Ministerialbeamte betraut. Viele Lehrer gehörten zu den Begründern der unterrichteten Wissenschaftsdisziplinen in der Tschechoslowakei oder waren direkt an der Gesundheits- und Sozialpolitik und ihrer legislativen Stützen beteiligt. In der Art des Unterrichts unterschied sich die Staatliche Masarykschule von der etablierten Organisation an den normalen Fürsorgeschulen, an denen die medizinischen Fächer nur von Ärzten unterrichtet wurden. Dank dem Umstand, dass die praktische Unterweisung in den medizinischen Fächern von Instruktorinnen besorgt wurde, entsprach der Unterricht der geforderten Praxisnähe. 
Bis zum Ausbruch des Zweiten Weltkriegs wurden an der Staatlichen Masarykschule insgesamt drei Jahrgänge eröffnet: der erste im Februar 1936, der zweite im September 1937 und der dritte im September 1938. Die Zahl der in einem Jahr in die tschechische und die deutsche Abteilung aufgenommenen Schülerinnen bewegte sich zwischen 48 und 52. Die Schule wurde zur Zufluchtsstätte für Töchter aus verfolgten deutschen sozialdemokratischen und jüdischen Familien und aus Kreisen reichsdeutscher und russischer Emigranten.

Deutsche Übersetzung Wolf B. Oerter

Růžena Zaoralová

Střední zdravotnická škola a Vyšši odborná škola zdravotnická Emanuela Pöttinga, Olomouc ruzena.zaoralova@seznam.cz

Roman Zaoral

Fakulta humanitnich studii Univerzity Karlovy, Praha

zaoral@post.cz 